\title{
Explosive pollen release, stigma receptivity and pollen dispersal pattern of Boehmeria caudata Sw. (Urticaceae) in a Brazilian rain forest
}

\begin{tabular}{|r|l|}
\hline Journal: & Botany \\
\hline Manuscript ID & cjb-2016-0031.R2 \\
\hline Manuscript Type: & Article \\
\hline Date Submitted by the Author: & 04-May-2016 \\
\hline Complete List of Authors: & $\begin{array}{l}\text { Montoya-Pfeiffer, Paula; Instituto de Biociências, Universidade de São } \\
\text { Paulo, Brasil, Laboratorio de Abelhas, Departamento de Ecologia } \\
\text { Kevan, Peter; University of Guelph, School of Environmental Biology } \\
\text { González-Chaves, Adrian; Universidade de Sao Paulo, Departamento de } \\
\text { Ecologia, Instituto de Biociências, } \\
\text { Pereira Queiroz, Elisa; Universidade de Sao Paulo Campus de Ribeirao } \\
\text { Preto, Faculdade de Filosofia, Ciências e Letras } \\
\text { Dec, Enderlei; Universidade de Sao Paulo Campus de Ribeirao Preto, } \\
\text { Faculdade de Filosofia, Ciências e Letras }\end{array}$ \\
\hline Keyword: & $\begin{array}{l}\text { Anemophily, Dioecy, Pollination, Meteorological conditions, Ombrophilous } \\
\text { forest }\end{array}$ \\
\hline \multicolumn{2}{|c}{} \\
\hline
\end{tabular}


Explosive pollen release, stigma receptivity and pollen dispersal pattern of Boehmeria caudata $\mathrm{Sw}$.

\section{(Urticaceae) in a Brazilian rain forest}

Paula Maria Montoya-Pfeiffer ${ }^{1}$, Peter G. Kevan², Adrian González-Chaves ${ }^{3}$, Elisa Pereira Queiroz ${ }^{4}$, Enderlei $\operatorname{Dec}^{5}$

${ }^{1}$ Laboratorio de Abelhas, Departamento de Ecologia, Instituto de Biociências, Universidade de São Paulo, Brasil, paulammpfeiffer@gmail.com

${ }^{2}$ School of Environmental Sciences, University of Guelph, Guelph, Ontario N1G 2W1, Canada, pkevan@uoguelph.ca

${ }^{3}$ Laboratorio de Abelhas, Departamento de Ecologia, Instituto de Biociências, Universidade de São Paulo, Brasil, adgonzalez86@gmail.com

${ }^{4}$ Faculdade de Filosofia, Ciências e Letras de Ribeirão Preto, Universidade de São Paulo, Brasil, elisa_queiroz@usp.br

${ }^{5}$ Faculdade de Filosofia, Ciências e Letras de Ribeirão Preto, Universidade de São Paulo, Brasil, enderlei@usp.br

Running title: Explosively delivered pollen in Boehmeria caudata

\section{Corresponding Author:}

Peter G. Kevan

pkevan@uoguelph.ca

School of Environmental Science 27

University of Guelph, Guelph, Ontario N1G 2W1, Canada 28 


\begin{abstract}
Male flowers of the wind-pollinated, dioecious shrub Boehmeria caudata release pollen explosively possibly stimulated by anther dehydration in response to temporarily dry conditions and coupled with hydrostatic pressure in the filament. In the Brazilian Atlantic rain forest, the daily frequency of male flower anthesis peaked between 10:00-12:00 h (GMT - 3) and was positively correlated with rising temperature, wind currents and direct insolation, but negatively correlated with relative humidity. A generalized linear mixed model predicts the probability of pollen release under different conditions of relative humidity and wind. Receptive stigmas on female flowers were found at any time of day: individual stigmas were receptive $\left(\mathrm{H}_{2} \mathrm{O}_{2}\right.$ test) for at least two days. Beetles and halictid bees were observed feeding on pollen from staminate flowers, but probably do not effect pollination because they do not seem to visit pistillate flowers. Individual plants of this apparently ruderal species grow along road edges and showed aggregated (clumped) spatial dispersion. The overall sex ratio was 29 females to 43 males with one monoecious plant in a total transect distance of 6,319 m. Pollen traps were placed on female plants to measure pollen arrival. Pollen capture was higher on the more exposed road-facing side and positively related to male plant density.
\end{abstract}

Keywords: anemophily - dioecy - meteorological conditions - Ombrophilous forest - pollination wind. 


\section{Introduction}

Wind pollination, or anemophily, has been considered a rare pollination strategy in tropical and other rain forests because environmental conditions are unsuitable: high moisture and rain wash pollen grains from the air; widely spaced conspecifics and abundance of animal vectors would select for a more efficient zoophilous long-distance pollination; plant species diversity, perpetual leafiness and little wind turbulence constitute barriers for wind pollination (Janzen 1975, Regal 1982, Whitehead 1983). Nevertheless, several findings suggest anemophily in tropical rain forests should not be dismissed (Bawa and Crisp 1980, Lewis 1986, Bullock 1994, Maués 2006, Friedman and Barrett 2009, MacInnis et al. 2014). In tropical rain forests, rain tends to be seasonal and is not continual throughout the day, even in the rainy season. Moreover, humidity, although generally high, varies with time of day as do temperature and insolation at the micrometeorological scale (e.g. Kumagai et al. 2001). The leafiness of the forest seems not be such a strongly effective filter of airborne pollen as presumed (MacInnis et al. 2014), and there are places, such as clearings and shorelines, where there is wind and atmospheric turbulence and plant dispersion is often clumped.

Boehmeria caudata $\mathrm{Sw}$. is an anemophilous species broadly distributed in the neotropics, from southern North America to northern Argentina, where it is commonly found in ruderal, open and mesic sites (Martins and Pirani 2010). It is mainly dioecious to rarely monoecious, ("leaky dioecy" of Baker and Cox 1984), growing as shrubs about 1.5 - $6 \mathrm{~m}$ high. Its floral form is well-fitted to the anemophilous syndrome (Faegri and van der Pijl 1979): small unisexual flowers with reduced and inconspicuous perianths, lacking rewards and attractants such as nectar, odor, or color associated with zoophily. The inflorescences are welldeveloped pendulous catkins with numerous flowers ( 400-600), the stigmas are feathery and ovule number reduced to one. Pollen grains are powdery and abundant ( 170000 per anther (personal observations)), relatively small (11-15 $\mu \mathrm{m})$, isopolar, oblate-spheroidal, triporate and smooth. For Urticaceae species in general, pollen grains are presumed to have low longevity and no pollenkitt, and be partially hydrated and starchless (Baker and Baker 1979, Bassani et al. 1994, Nepi et al. 2001, Franchi et al. 2002, Pacini and Hesse 2005).

Male flowers have an autochthonous explosive pollen release mechanism, different from other species, such as in various legumes, Kalmia (Ericaceae), Bruguiera mangroves (Rhizophoraceae) and others, where the mechanism is mediated by flower visiting animals. It is common in the families Urticaceae and 
Cannabaceae and the tribe Morae (Kerner von Marilaun1904, Knuth 1909, Taylor et al. 2006), as well as in a few other plants, including Cornus canadensis (Cornaceae) of the North American temperate forest floor (Mosquin 1985, Edwards et al. 2005), Ricinus communis (Euphorbiaceae) (Bianchini and Pacini 1996) and Solandra spp. (Solanaceae) (the large corolla, in anthesis, swells like a balloon and bursts open while liberating a cloud of pollen from the already dehisced anthers within (R. Bye, personal communication 29 January, 2015)). In Urticaceae, the violent reflexion of the inflexed stamens causes the anthers to undergo a catapulting motion, inertially releasing pollen (Fig. 1, supplementary video S1). It is thought that the dehydration of anthers, coupled with hydrostatic pressure in the filament, causes an increase of the elastic tension until the point of release and resulting pollen liberation. The mechanisms, floral anatomies and environmental conditions for this kind of explosive pollen release in Urtica, Parietaria, Pilea, and Broussonetia are briefly and beautifully described by Kerner von Marilaun (1904). Hildebrand (1867), Delpino (1868 - 1875) and MacLeod (1894) published earlier observations on Urtica. A detailed analysis of the biomechanics of this mechanism in Morus alba found velocities in excess of half the speed of sound, corresponding to the fastest motion jet observed in biology (Taylor et al. 2006). Jackes and Hurley (1997) noted under a dissecting microscope, dissimilar explosive pollen release of two species of Dendrocnide: in D. cordifolia, the $3 \mathrm{~mm}$ long filaments slowly uncoiled and then showered everything in sight with pollen, but D. moroides with a filament less than $1 \mathrm{~mm}$ long did not appear to do this. This explosive reaction seemed to be caused by atmospheric changes in moisture (drying) and heating on the microscope stage.

For the tribe Boehmerieae, it has been proposed that explosive release of pollen and sexual separation of the flowers (dioecy or monoecy) has existed since Tertiary times (Poinar et al. 2016). Hutton (1986) noted explosive pollen release in extant B. calophleba, endemic to Lord Howe Island, Australia. Qiu (1986), making observations by dissecting and scanning electron microscopes of male flowers of $B$. nivea, attributed the explosive release of pollen to unequal shrinking of the fibrous layer of cells of the anther wall, causing the anther to rupture, while the inner cushion-shaped epidermal cells of the filaments expanded to uncurl the stamen. In Asia the genus is complex, with taxa recorded as apomictic and unisexually female or male-sterile, tending to range into higher latitudes and more disturbed habitats than their sexual relatives (Yahara 1990), but that study does not record the mechanism of pollen release in taxa with staminate flowers. 
After we had observed explosive pollen release in B. caudata, our aim was to analyze the timing and environmental conditions under which this mechanism takes place, as well as to determine if stigmatic receptivity periods were also similarly constrained. Given that it is assumed that a clumped distribution of the opposite-sex individuals would be essential for wind pollination (Whitehead 1983, DiGiovanni and Kevan 1991, Bassani et al. 1994, Pacini et al. 1997), here we also examine how the spatial dispersion pattern of conspecifics may facilitate pollen arrival to female plants for pollination. Finally, we discuss how all these factors represent adaptations for an anemophilous species in a rain forest.

\section{Methodology}

The study was conducted at the Parque Estadual Intervales, State of São Paulo, Brazil (24¹6,288' S, $48^{\circ} 25,045^{\prime} \mathrm{W}, 820$ masl). The area constitutes one of the biggest remnants of the Atlantic Forest Biome (Mata Atlântica) with a predominant vegetation cover of Ombrophilous Dense Forest, little affected by human disturbance. The region's climate was classified by Strahler (1975) as subtropical moist, dominated by seasonally fluctuating tropical and polar air masses. Monthly mean temperature varies between $14^{\circ} \mathrm{C}$ and $22^{\circ} \mathrm{C}$ (annual mean $18^{\circ} \mathrm{C}$ ), precipitation between $66 \mathrm{~mm}$ and $270 \mathrm{~mm}$ per month (annual mean 1500-2000 $\mathrm{mm}$ ) and relative humidity is always above $80 \%$. The rainiest season occurs in summer between December and March (i.e. when we made our study), and the driest in winter between June and August (Fundação Florestal 2009).

Our study took place between December 8th and 19th 2014 with detailed observations made from December 15th $(14: 00 \mathrm{~h})$ to 17 th $(14: 00 \mathrm{~h})$. Staminate floral anthesis was registered at two-hour intervals, from 06 to 18 hours (GMT -3), on five male and one monoecious plant (343 total observations). On each plant, five catkins $10-20 \mathrm{~cm}$ in length and with no more than 10 opened flowers were selected. At the start of every observation period, the numbers of opened flowers were recorded and the flowers removed. As a second measurement for staminate flower anthesis, we recorded the number of pollen release events (i.e. pollen clouds visibly released from flowers (Fig. 1, supplementary video S1)) as seen by one observer on each plant, during a one-minute period twice during every two-hour interval (160 total observations).

Stigma receptivity was measured on six female plants, every two hours, by placing small drops of hydrogen peroxide (10\% concentration, Dafni et al. 2005) on three stigmas randomly selected on each plant. 
The presence of bubbles on the stigmas indicating receptivity was monitored under a magnifying glass (10x) (420 total observations).

Meteorological conditions were recorded at the same two-hour intervals, immediately after recording the number of pollen release events per minute on each plant. Air temperature and relative humidity (RH) were measured by digital thermohygrometer. Shade and insolation was recorded as presence or absence. Wind force and direction were qualitatively measured by observing the pendular movement of a string ( $52 \mathrm{~cm}$ in length, $543.8 \mathrm{mg}$ ) by registering the angle deflected from vertical by wind as follows: 0 : no wind $\left(0^{\circ}\right)$; 1 : very low $\left(0-22.5^{\circ}\right) ; 2$ : low $\left(22.5-45^{\circ}\right)$; 3 : strong $\left(45-67.5^{\circ}\right)$; 4 : very strong $\left(67.5-90^{\circ}\right)$.

Statistical analyses were performed in R (The R Foundation for Statistical Computing 2011) using simple correlation analyses and generalized mixed linear models (package lme4). The number of explosions per minute per plant was transformed into a presence-absence response variable (binomial probability distribution). Full models started with fixed effects of RH, wind (presence-absence) and their interaction. Temperature and shade and insolation were not included in the model due to collinearity with RH $(>0.8)$. Plant identity was included as a random effect. The structure of random effects was selected by using parametric bootstrap and stepwise model simplifications were based on lower AIC values. Model fitting was measured by residual analysis (packages arm and influence.ME), r-squared values (package MuMIn), the ratio deviance/df, ROC curves and AUC values (package ROCR).

The spatial dispersion of B. caudata plants was analyzed by measuring nearest neighbour distances between individuals found along a road transect of $1544 \mathrm{~m}$ and then calculating the Clark-Evans index (1954). To estimate the sex ratio, the numbers of female, male and monoecious plants were recorded on three roads and one walking trail for a total distance of $6319 \mathrm{~m}$.

We made a small experiment to assess the arrival of airborne pollen on female plants. We used pollen traps ("megastigmas") as described by Kevan et al. (2006). They consisting of plastic horticultural labels $(15 \times 3 \times 0.1 \mathrm{~cm})$ with 28 punched holes each. Transparent sticky tape was applied along the underside of the label so that each hole constituted a sticky pollen-trapping surface. Pollen traps were placed for 48hours on each side of seven female plants: forest-facing, forwards (road-facing), left and right (perpendicular to the road). Pollen counts were made microscopically (40x) on six holes randomly chosen on each pollen trap. 
By using a generalized linear model associated to a negative binomial distribution, we evaluated airborne pollen densities in relation to the orientation of the sides of female plants and male plant density around each chosen female plant (number of male plants present within 5m). Model fitting was measured by residual analysis and the ratio deviance/df.

\section{Results}

During cloudy and rainy days and at night, we observed no pollen release events. The intense observation period was characterized by sunny weather, without major differences in meteorological conditions between days. Temperature varied between $43^{\circ} \mathrm{C}$ and $15^{\circ} \mathrm{C}$ (mean $27.54^{\circ} \mathrm{C}$, s.d. 7.63 ) and $\mathrm{RH}$ between $26 \%$ and $86 \%$ (60.81\%, s.d. 16.18) (Fig. 2). The observed individuals of B. caudata were well exposed to the sky from 8:00 to 18:00 h, with slight variations on the more shadowy individuals (Fig. 3). Wind forces were registered only in $33 \%$ of the observations $(n=159)$, most of the cases with a "very low" force (category 1, 93\%). Wind direction was unpredictable (W=26.6\%; $\mathrm{E}=20.3 \% ; \mathrm{S}=17.2 \% ; \mathrm{N}=14.1 \%$; $\mathrm{SE}=12.5 \%$, SW-NW-NE=3.1\%), but seemed mostly parallel to the road direction.

Statistical correlations were found between male flower anthesis and the recorded abiotic factors. The number of flowers on each inflorescence that opened during the two-hour period varied between 0 and 25 (mean 2.07, s.d. $3.07,<6 \%$ of flowers per inflorescence), with a peak at 10:00-12:00 h, and was negatively correlated with RH but positively correlated with temperature and direct insolation (Pearson correlation coefficients $>0.7$, $\mathrm{p}$ - values $<0.01$ ). Pollen release observations per minute varied between 0 and 35 (mean 1.94, s.d. 4.62), with a similar diurnal pattern and positively correlated with direct insolation and wind force (Pearson correlation coefficients $>0.2$, p- values $<0.05$ ) (Fig. 3).

The probability of registering pollen release events was explained by the additive effects of relative humidity $(\mathrm{RH})$ and the presence of wind (GLMM associated to binomial distribution, $\mathrm{R}^{2}$ (marginal) $=0.28$, ratio deviance $/ \mathrm{df}=0.89)$, but not by the interaction between these two variables ( $\mathrm{p}$-value $=0.18)$. The identity of the individual male plants accounted for $12 \%$ of the residual variance (random effect on the intercept, $\mathrm{R}^{2}$ (conditional) $\left.=0.37\right)$. The odds ratio of pollen release events was 2.86 (Confidence Interval $(\mathrm{CI})$ $=1.26-6.76$ ) times higher when wind could be detected and decreased by the effect of $\mathrm{RH}$, at the rate of 0.94 
$(\mathrm{CI}=0.91-0.96 ; \mathrm{p} \leq 0.001)$ (Fig. 4$)$. The equations that predict the odds ratio $(\pi)$ of pollen release events are:

$\pi($ no wind $)=\frac{\exp [2.08-0.05 * R H]}{1+\exp [2.08-0.05 * R H]}$

$\pi($ wind $)=\frac{\exp [3.13-0.05 * R H]}{1+\exp [3.13-0.05 * R H]}$

The ROC curve and the value for the Area Under the Curve (AUC) indicated that the GLMM correctly predicts the occurrence of pollen release events in $67 \%$ of the cases (see Fielding and Bell 1997).

Stigmas were recorded as receptive $\left(\mathrm{H}_{2} \mathrm{O}_{2}\right.$ test $)$ at any time of the day ( $100 \%$ of observations), without being correlated with meteorological parameters. However, at noon during the peak of male flower anthesis, we saw more bubbles (not quantifiable) produced by the hydrogen peroxide, probably indicating the period of greatest receptivity.

During the course of the observations, we saw beetles and halictid bees on staminate flowers feeding on pollen but never saw insects on pistillate flowers.

Individuals of $B$. caudata distributed along road edges showed an aggregated dispersion pattern (Clark-Evans Index: 0.25, p < 0.001, $1544 \mathrm{~m}, 34$ individuals). Our study population was generally malebiased (29 females, 43 males, 1 monoecious over 6319 m), i.e. a not quite statistically significant higher male proportion (Chi-square test $(\mathrm{H}$ sex ratio $1: 1)=2.722 ; \mathrm{p}=0.099)$. A female bias was found in one subtransect (13 females, 9 males over $250 \mathrm{~m}$ ).

Mean airborne pollen density around female plants varied between 0 and 58 pollen grains per megastigma (mean 8.9, s.d. 15.0). Some of this variation (35\%) was explained by the interaction of the orientation of the traps with respect to the open area (roadway) and male density (over-dispersion coefficient 1.4) (Fig. 5). For traps on the sides of female plants perpendicular to the road, the predicted initial pollen density (i.e. with male density $=0$ ), was 13.6 (CI: $5.0-40.8, \mathrm{p}<0.001)$ and there was no significant effect of male density on airborne pollen $(-0.3, \mathrm{CI}:-3.8-0.1, \mathrm{p}=0.17)$. At the forest facing side, the initial pollen density was slightly less $(13.47, \mathrm{CI}: 12.9-13.58, \mathrm{p}=0.01)$ and rose with male density by a rate of 20.24 grains $/$ male plant present $(\mathrm{CI}:-1.0-600.7$, $\mathrm{p}$-value $=0.06)$. At the road facing side, the initial pollen density was almost the same $13.51(\mathrm{CI}: 12.8-13.6, \mathrm{p}$-value $=0.01)$ but the rate of increase was nine times higher (191.0, CI: $4.33-9405.5, \mathrm{p}=0.003)$. 


\section{Discussion}

We note several adaptations and factors that would facilitate pollination of B. caudata under the high moisture conditions of a rain forest.

First, its explosive pollen release mechanism is advantageous in more or less still environments because pollen grains can be emitted beyond the boundary layer of the plant and then, entrained by even feeble air currents and transported away farther from the parent plant (Bianchini and Pacini 1996, Taylor et al. 2006). Second, the apparently quick response of male flowers to the diurnal and minute-to-minute variations in temperature, insolation, moisture and wind allows opportunistic pollen release. We found a well-defined short period of pollen release (10 a.m. to noon.) in B. caudata when humidity is lowest and insolation relatively strong, being consistent with data obtained from other Urticales with explosive pollen release (Bawa and Crisp 1980, Bullock 1994, Trigo et al. 1996, Crimi et al. 2004, de La Guardia et al. 1998). Even so, the optimum ranges of environmental parameters and daily periods of pollen release for different species and their locally adapted biotypes, probably varies between ecosystems and intra-diurnal vagaries. The meteorological conditions we recorded would cause dehydration of the stamens, which is known to trigger anther dehiscence and pollen release in some species (Qiu 1986, Lisci et al. 1994, Bianchini and Pacini 1996, Edwards et al. 2005, Taylor et al. 2006, Franchi et al. 2007). At night and during periods of high moisture intrinsic mechanisms, such as reabsorption of moisture through the vascular tissue, anther dehiscence would be reduced (Pacini, 2000). During the day, direct insolation would heat the catkins (as has been found for Salix spp., Salicaceae (Kevan 1990)), and may amplify micrometeorological effects on pollen liberation.

The independent life of airborne pollen is poorly known. Pollen dispersal is favored by pollen grain dehydration, which results in loss in mass and therefore, a gain in buoyancy in air (Lisci et al. 1994, Crimi et al. 2004). However, for B. caudata those effects and concomitant loss in pollen mass might small because in Urticaceae pollen grains remain partially hydrated and so maintain viability (Bassani et al. 1994, Nepi et al. 2001), despite the lack of starch and consequent vulnerability to desiccation (Baker and Baker 1979, Dafni and Firmage 2000). The remarkably short viability of anemophilous pollen (Ponomarev and Banikova 1969, 
Hammer 1977, Franchi et al. 2002, Huang et al. 2004, Wang et al. 2004) attests to the hostile nature of the atmosphere for pollen. We did not measure pollen viability and longevity directly and the inferences we make need to be tested. Once pollen lands on a stigma it can rehydrate and germinate (Heslop-Harrison 1987, Lisci et al.1994).

Wind force seemed to have little effect over the broad hourly range, but the positive effect on the number of pollen release observations per minute suggests that low atmospheric moisture conditions coupled with wind constitute the 'tripping' agent (Timerman et al. 2014). More detailed studies and micrometeorological measurements would be needed to elucidate those points for B. caudata.

We cannot exclude the possibility that flower visitors feeding on pollen and so touching the anthers also contribute to the explosive mechanism, as for example occurs in R. communis (Rizzardo et al. 2012). At the start of our study we experimentally touched the filaments with a needle and caused explosions (Fig.1). Even so, flower visitors would not help directly in pollination if they did not visit female flowers.

Third, prolonged stigma receptivity could allow for the asynchronous male flower anthesis and the subsequent prolonged pollen availability to be effective. Here, the assumption of complementarity between the duration of stigma receptivity and pollen viability and longevity (Dafni and Firmage 2000) seems not to apply. Receptive stigmas were found at any time of day without being correlated with meteorological parameters. On the other hand, the lack of a pronounced periodicity of stigma receptivity may be disadvantageous for a wind- pollinated species because alien pollen can be deposited during the absence of domestic pollen that would otherwise effect fertilization. Stigma clogging (Lloyd and Webb 1986) and alien pollen allelopathy (Murphy 1992) suggest themselves.

A fourth adaptation may be the male-biased sex ratio for $B$. caudata $(1: 1.5$ : female: male plants $(\mathrm{n}=$ 72)) as is common in dioecy and especially anemophiles. It is considered as a bet-hedging strategy against the probability of any one grain reaching a stigma being so low (Ackerman 2000, Friedman and Barrett 2009). Nevertheless, it is interesting that in one of the four trails examined which was narrower that the other ones (it was a walking trail whereas the others were vehicular roads), there was a higher proportion of females. The peculiar characteristics of this trail could have created an environmental effect favouring female bias, as it has been suggested for other species, where sex-spatial segregation results from sex-competition or differential use of resources (Bawa, 1980; Bierzychudek and Eckhart, 1988; Friedman and Barrett, 2009). For 
some wind-pollinated dioecious species, Freeman et al. (1976) proposed that male success may be higher on windy slopes because of more effective pollen dispersal, whereas female success may be relatively higher on lower-lying sites where pollen may accumulate and soil is relatively moister during seed and fruit maturation.

Fifth, the clumped dispersion along open areas would facilitate pollen dispersal and arrival on female plants. Populations of $B$. caudata were distributed along forest edges that presumably allow opportunities for pollen dispersal because of a better exposure to insolation, daily atmospheric turbulence due to thermal convections and often mid-morning winds prior to rains (Lewis 1986). We noticed that the wind directions were parallel to the forest edge (road direction) that served as channels guiding pollen clouds from male plants to females distributed nearby (Fig.5). Although it is to be expected that the interception of pollen on stigmas would be related to wind direction and strength, as noted by Lisci et al. $(1994,1996)$ for Mercurialis annua, other subtle aerodynamic effects may contribute to evening the dispersion of pollen capture round female reproductive structures, such as the megastrobili of Pinus (Roussy and Kevan 2000).

Boehmeria caudata also had clumped dispersion, atypical of the traditional assumption that conspecific individuals in species-rich tropical communities are widely spaced (Janzen 1975) but in accord with clumped plant dispersions typical of several forest types from temperate and tropical latitudes (Bullock 1994). Clumped dispersion is considered advantageous for wind pollination because airborne pollen has a leptokurtic density distribution from point sources (Whitehead 1983, DiGiovanni and Kevan 1991). Dafni and Firmage (2002) noted that pollen longevity is unimportant for pollen making only short flights. Furthermore and not surprisingly, various studies have demonstrated that pollination success is negatively correlated with plant spacing in both anemophilous (e.g. Friedman and Barrett 2009) and zoophilous (Hubbel 1979, Condit et al. 2000) plants. For B. caudata we did find less airborne pollen on pollen traps on female individuals more isolated from males (Fig. 5) and more on the open exposed side.

We do not know about other flowering periods of $B$. caudata in the study site, nor in other parts of its extensive range, but we found it flowering in December during the summer rainy season. Other species with the same pollen release mechanism also have been found flowering in association with wet periods or with dry intervals preceded by rainy periods (Bullock 1994, Trigo et al. 1996, de La Guardia et al. 1998). In temperate regions, seasonality dictates flowering (i.e. many phenological studies) and floral anthesis itself correlates with various weather conditions, micrometeorological diel periodicities, and time of day. Few 
studies elucidate the influences of even some of those different factors and so cannot be used for conjecture about anthecology in B. caudata. We note that B. caudata presumably needs moisture to produce flowers, cause the filaments to become turgid, and so be responsible for the elastic tension and explosive mechanism (Qiu 1986, Edwards et al. 2005, Taylor et al. 2006, Franchi et al. 2007). Dry spells during certain hours of the day in the rainy season could be the special combination needed for functional flowering and pollination in $B$. caudata as Bullock (1994) suggested for tropical dioecious trees. The finding of Boehmeria-like flowers of Ekrixanthera explosively releasing pollen in Tertiary amber (Poinar et al. 2016) suggests that they may have been broken from the parent plants at the same time they became fossilized during unsettled weather (high winds, insolation, and low humidity).

Our observations are not sufficient to demonstrate explicitly the adaptive mechanisms involved in the pollen release events of male flowers, the pollen capture mechanisms and receptivity of the stigmas for the female flowers, and how they would respond specifically to any of the meteorological variables or the interactions between them. Detailed and manipulative experiments, under controlled conditions, would be necessary to eliminate the effects of collinearity in the regressions which are imposed by intrinsic correlations between the climatic variables, as well as the effects of other not-measured ones. Replications throughout the extended geographic range of B. caudata would be ideal as well. Even though, our findings should serve as the starting point for new studies. Herein, we provide a pool of hypotheses about the pollination mechanism of B. caudata.

\section{Acknowledgements}

We thank the organization and the staff of the International Pollination Course Intervales- 2014 (Projeto Polinizadores do Brasil) for their collaboration and support. We are grateful for personal communications and information from Ian Hutton (Lord Howe Island), Robert Bye (Mexico) and Betsy Jackes (Queensland).

\section{References}

Ackerman, J.D. 2000. Abiotic pollen and pollination: ecological, functional, and evolutionary perspectives. Plant Syst. Evol. 222(1): 167-185. doi:10.1007/BF00984101. 
Baker, H.G., and Baker, I. 1979. Starch in angiosperm pollen grains and its evolutionary significance. Amer. J. Bot. 66(55): 591-600.

Baker, H.G., and Cox, P.A. 1984. Further thoughts on dioecism and islands. Ann. Mo. Bot. Gard. 71(1): 244253. doi:10.2307/2399068.

Bassani, M., Pacini, E., and Franchi, G.G. 1994. Humidity stress responses in pollen of anemophilous and entomophilous species. Grana 33(3): 146-150.

Bawa, K.S. 1980. Evolution of dioecy in flowering plants. Annu. Rev. Ecol. 11: 15-39.

Bawa, K.S, and Crisp J.E. 1980. Wind-pollination in the understorey of a rain forest in Costa Rica. J. Ecol. 68(3): 871-876. doi: $10.2307 / 2259462$.

Bianchini, M., and Pacini, E. 1996. Explosive anther dehiscence in Ricinus communis L. involves cell wall modifications and relative humidity. Int. J. Plant Sci. 157(6), 739-745.

Bierzychudek, P., and Eckhart, V. 1988. Spatial segregation of the sexes of dioecious plants. Am. Nat. 132(1): 34-43.

Bullock, S.H. 1994. Wind pollination of neotropical dioecious trees. Biotropica 26(2): 172-179. doi: $10.2307 / 2388806$.

Clark, P.J., and Evans, F.C. 1954. Distance to nearest neighbor as a measure of spatial relationships in populations. Ecology 35(4): 445-453. doi: 10.2307/1931034.

Condit, R., Ashton, P.S., Baker, P., Bunyavejchewin, S., Gunatilleke, S., Gunatilleke, N., Hubbell, S.P., Foster, R.B., Itoh, A., LaFrankie, J.V., Lee, H.S., Losos, E., Manokaran, N., Sukuwar, R., and Yamakura, T. 2000. Spatial patterns in the distribution of tropical tree species. Science 288(5470): 1414-1418. doi: $10.1126 /$ science.288.5470.1414

Crimi, P., Macrina, G., Folli, C., Bertoluzzo, L., Brichetto, L., Caviglia, I., and Fiorina, A. 2004. Correlation between meteorological conditions and Parietaria pollen concentration in Alassio, north-west Italy. Int. J. Biometeorol. 49(1): 13-17.

Dafni, A., and Firmage, D. 2000. Pollen viability and longevity: practical, ecological and evolutionary implications. Plant Syst. Evol. 222:113-132.

Dafni, A., Kevan, P.G., and Husband, B.C. 2005. Practical pollination ecology. Enviroquest, Cambridge, Ontario. 
de La Guardia, C.D., Alba, F., Girón, F., and Sabariego, S. 1998. An aerobiological study of Urticaceae pollen in the city of Granada (S. Spain): Correlation with meteorological parameters. Grana 37(5): 298-304. doi: $10.1080 / 00173139809362682$.

Delpino, F. 1868 - 1875. Ulteriori osservazioni sulla dicogamia nel regno vegetale. Part I (1868-69), Part II, fasc. 1 (1870) and fasc. 2 (1875). From Müller (1883: 520)

DiGiovanni, F., and Kevan, P.G. 1991. Factors affecting pollen dynamics and its importance to pollen contamination: A review. Canad. J. Forest Res. 21(8): 1155-1170. doi:10.1139/x91-163.

Edwards, J., Whitaker, D., Klionsky, S., and Laskowski, M.J. 2005. A record-breaking pollen catapult. Nature 435: 164. doi:10.1038/435164a

Faegri, K., and van der Pijl, L. 1979. Principles of pollination ecology ( $3^{\text {rd }}$ revised edition). Pergamon Press, Oxford, UK.

Fielding, A.H., and Bell, J.F. 1997. A review of methods for the assessment of prediction errors in conservation presence/absence models. Environmental conservation, 24(01): 38-49.

Franchi, G.G., Nepi, M., Dafni, A., and Pacini, E. 2002. Partially hydrated pollen: taxonomic distribution, ecological and evolutionary significance. Plant Syst. Evol. 234(1): 211-227. doi: 10.1007/s00606-002-02211.

Franchi, G.G., Nepi, M., Matthews, M.L., and Pacini, E. 2007. Anther opening, pollen biology and stigma receptivity in the long blooming species, Parietaria judaica L.(Urticaceae). Flora 202(2): 118-127.

Freeman, D.C., Klikoff, L.G., and Harper, K.T. 1976. Differential resource utilization by the sexes of dioecious plants. Science 193(4253): 597-599.

Friedman, J., and Barrett, S.C. 2009. Wind of change: new insights on the ecology and evolution of pollination and mating in wind-pollinated plants. Ann. Bot. 103(9): 1515-1527. doi:10.1093/aob/mcp035.

Fundação Florestal. 2009. Plano de manejo do Parque Estadual Intervales [online]. Available from: http://fflorestal.sp.gov.br/planos-de-manejo/planos-de-manejo-planos-concluidos/_[accessed January 2015].Hammer, K., 1977. Fragen der Eignung des Pollens der Kulturgerste (Hordeum vulgare L. s. 1.) für die Windbestäubung. Die Kulturpflanze 25: $13-24$.

Heslop-Harrison, J. 1987. Pollen germination and pollen tube growth. Int. Rev. Cytol. 107:1-78

Hildebrand, D. 1867. Die Geschelechts-Verteilung bei den Pflanzen. Leipzig. Pp. 18 - 19. 
Huang, Z. H., Zhu, J. M., Mu, X. J. and Lin, J. 2004. Pollen dispersion, pollen viability and pistil receptivity in Leymus chinensis. Annals of Botany 93: 295-301.

Hubbell, SP. 1979. Tree dispersion, abundance, and diversity in a tropical dry forest. Science, New Series 203(4387): 1299-1309. doi: 10.1126/science.203.4387.1299.

Hutton, I. 1986. Lord Howe Island, discovering Australia's world heritage. Conservation Press, Australia. Jackes, B.R., and Hurley M. 1997. A new combination in Dendrocnide (Urticaceae) in north Queensland. Austrobaileya 5(1): 121-123.

Janzen, D.H. 1975. Ecology of Plants in the Tropics. Edward Arnold, London.

Kerner von Marilaun, A. 1904. The natural history of plants: Their forms growth reproduction and distribution. Trans by F.W. Oliver with assistance of L. Busk and Mrs. MF Macdonald. Volume II: 137 138. London: The Gresham Publishing Company.

Kevan, P.G. 1990. Sexual differences in temperature of blossoms on a dioecious plant, Salix arctica: significance for life in the arctic. Arctic and Alpine Res. 22: 283-289. doi: 10.2307/1551591.

Kevan, P.G, DiGiovanni, F., Ho, R., Taki, H., Ferguson, K.A., and Pawlowski, A.K. 2006. A simple method for collecting airborne pollen. J. Biol. Educ. 40(4): 181-183. doi:10.1080/00219266.2006.9656042.

Kevan, P.G., and Tikhmenev, E.A. 1996. Dynamic anemophily and the ecology of pollination in common grasses in Ontario. Russian J. Ecol. 27(4): 260-266.

Knuth, P. 1909. Handbook of flower pollination based upon Hermann Müller's work 'The fertilization of flowers by insects'. Volume III: 371 - 373. [Translated from German by J.R. Ainsworth Davis]. Clarendon Press, Oxford.

Kumagai, T., Kuraji, K., Noguchi, H., Tanaka, Y., Tanaka, K., and Suzuki, M. 2001. Vertical profiles of environmental factors within tropical rainforest, Lambir Hills National Park, Sarawak, Malaysia. J. Forest Res. 6: $257-264$.

Lewis, W. H. 1986. Airborne pollen of the neotropics: Potential roles in pollination and pollinosis. Grana 25(1): 75-83. doi:10.1080/00173138609429936.

Lisci, M., Tanda, C., and Pacini, E. 1994. Pollination ecophysiology of Mercurialis annua L.(Euphorbiaceae), an anemophilous species flowering all year round. Ann. Bot. 74(2), 125-135. 
Lisci, M. Cardinali, G., and Pacini, E. 1996. Pollen dispersal and role of pollenkitt in Mercurialis annua L (Euphorbiaceae). Flora 191(4): 385-391.Lloyd, D.G., and Webb, C.J. 1986. The avoidance of interference between the presentation of pollen and stigmas in angiosperms I. Dichogamy. New Zeal. J. Bot. 24(1): 135162.

MacInnis, G., Greene II, D., Straka, J., and Kevan, P.G. 2014. Particle filtration through a humid tropical forest canopy. Bol. Mus. Para. Emílio Goeldi. Cienc. Nat., Belém. 9(3): 455 - 463.

MacLeod, J. 1894. Over de bevruchting der bloemen in het kempisch gedeelte van vlaanderen. Botanische Jaarboek Dodoneaea 6: 119-511.Martins, E.G.A., and Pirani, J.R. 2010. Flora da Serra do Cipó, Minas Gerais: Urticaceae. Bol. Bot. USP. 28(2): 161-173.

Maués, M.M. 2006. Estratégias reprodutivas de espécies arbóreas e a sua importância para o manejo e conservação florestal; Floresta Nacional do Tapajós (Belterra-PA). Thesis. Universidade de Brasília. Mosquin, T. 1985. The explosive pollination mechanism in the pop flower, Chamaepericlymenum (Cornaceae). Can. Field-Nat. 99(1): 1-6.

Murphy, S.D. 1992. The determination of the allelopathic potential of pollen and nectar. In Modern methods of plant analysis, vol. 13, Plant toxin analysis, Edited by H.F. Linskens, and J.F. Jackson. Springer-Verlag, Berlin. pp. 333-357.

Nepi, M., Franchi, G.G., and Pachini, E. 2001. Pollen hydration status at dispersal: cytophysiological features and strategies. Protoplasma 216(3-4), 171-180.

Pacini, E. 2000. From anther and pollen ripening to pollen presentation. Plant Syst.Evol. 222(1): 19-43.

Pacini, E., Franchi, G. G., Lisci, M., and Nepi, M. 1997. Pollen viability related to type of pollination in six angiosperm species. Annals Bot. 80: 83-87.

Pacini, E., and Hesse, M. 2005. Pollenkitt - its composition, forms and functions. Flora 200(5): 399-415.

Poinar, G.Jr, Kevan, P.G., and Jackes, B. 2015. Fossil species of Boehmeria Jacq. (Urticaceae) in Dominican and Mexican amber: Two new species, indications of anemophilous pollination by explosive pollen release, and lepidopteran herbivory. Botany (in press )

Ponomarev, A.N., and Banikova, V.A, 1969. On pollen viability in morning and afternoon grasses. Uchenye Zapiski Permsk Gosudarstvennyy Universitet No. 179, pp. 98-107. [in Russian] 
Qiu R. 1986. An anatomical study on the flowering mechanism of male flower of ramie (Boehmeria nivea). J. Wuhan Bot. Res. 4(2): 135-138.

Regal, P.J. 1982. Pollination by wind and animals: ecology of geographic patterns. Ann. Rev. Ecol. Syst. 13: 497-524.

Rizzardo, R.A., Milfont, M.O., Silva, E., and Freitas, B.M. 2012. Apis mellifera pollination improves agronomic productivity of anemophilous castor bean (Ricinus communis). An. Acad. Bras. Ciênc. 84(4): $1137-1145$.

Roussy, A.M., and Kevan, P.G. 2000. How accessible are receptive megastrobili to pollen? The example of Jack pine (Pinus banksiana). Am. J. Bot. 87(2): 215-220.

Strahler, A. 1975. Geografía física. Omega, Barcelona.

Taylor, P.E., Card, G., House, J., Dickinson, M.H., and Flagan, R.C. 2006. High-speed pollen release in the white mulberry tree, Morus alba L. Sex. Plant Reprod. 19(1): 19-24.

The R Foundation for Statistical Computing. 2011. R (version 2.14.1).

Timerman, D., Greene, D.F., Urzay J., and Ackerman, J.D. 2014. Turbulence-induced resonance vibrations cause pollen release in wind-pollinated Plantago lanceolata L.(Plantaginaceae). J. Roy. Soc. Interface.

11(101): 20140866. doi: 10.1098/rsif.2014.0866.

Trigo, M.M., Cabezudo, B., Recio, M., and Toro, F.J. 1996. Annual, daily and diurnal variations of Urticaceae airborne pollen in Málaga (Spain). Aerobiologia. 12(1): 85-90. doi:10.1007/BF02248131.

Wang, Z. Y., Ge, Y. X., Scott, M., and Spangenberg, G. 2004. Viability and longevity of pollen from transgenic and nontransgenic tall fescue (Festuca arundinacea) (Poaceae) plants. Amer. J. Bot. 91: 523-530. Whitehead D.R. 1983. Wind pollination: some ecological and evolutionary perspectives. In. Pollination biology. L. Real (ed.). Academic Press, Orlando. pp. 97-108.

Yahara, T. 1990. Evolution of agamospermous races in Boehmeria and Eupatorium. Plant Species Biol. 5: 183-196. doi: 10.1111/j.1442-1984.1990.tb00203.x 


\section{List of figures}

Figure 1. Pollen cloud produced after the explosive anther dehiscence. Credit: Rodrigo Y Castro, published with permission and thanks.

Figure 2. Daily environmental parameters: ambient air temperature and relative humidity (RH). Points on the scatter plot correspond to data gathered at the various locations, days (mostly from 15 - 17 December, 2014) and times where and when observations were made at Parque Estadual Intervales, SP, Brazil.

Figure 3. Male flower anthesis recorded by explosive pollen release events during the day, interacting with the presence-absence of wind currents and sun light.

Figure 4. Mean (black line) and 95\% confidence interval (grey band) of the probability of pollen release in relation to relative humidity $(\mathrm{RH})$ and the presence-absence of detectable wind currents.

Figure 5. Airborne pollen densities on megastigma pollen traps placed around seven female plants: facing the road, facing the forest, and perpendicular to the road. Mean (black line) and 95\% confidence interval (grey band) of the interaction of male density (plants $/ \mathrm{m}^{2}$ within $5 \mathrm{~m}$ ) and the position of pollen traps on airborne pollen density (pollen grains per trap). 


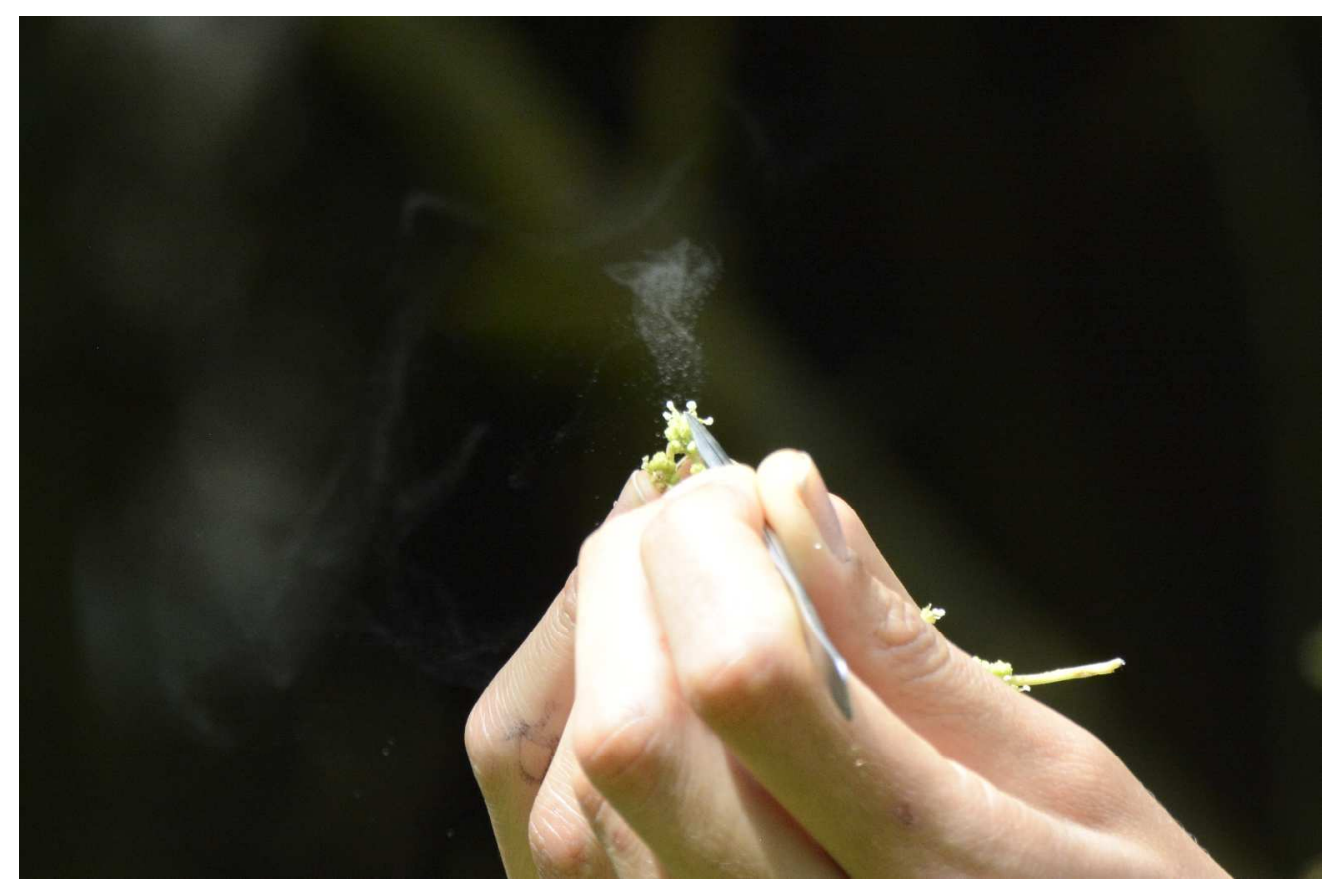

$252 \times 167 \mathrm{~mm}(300 \times 300$ DPI $)$ 
Botany.
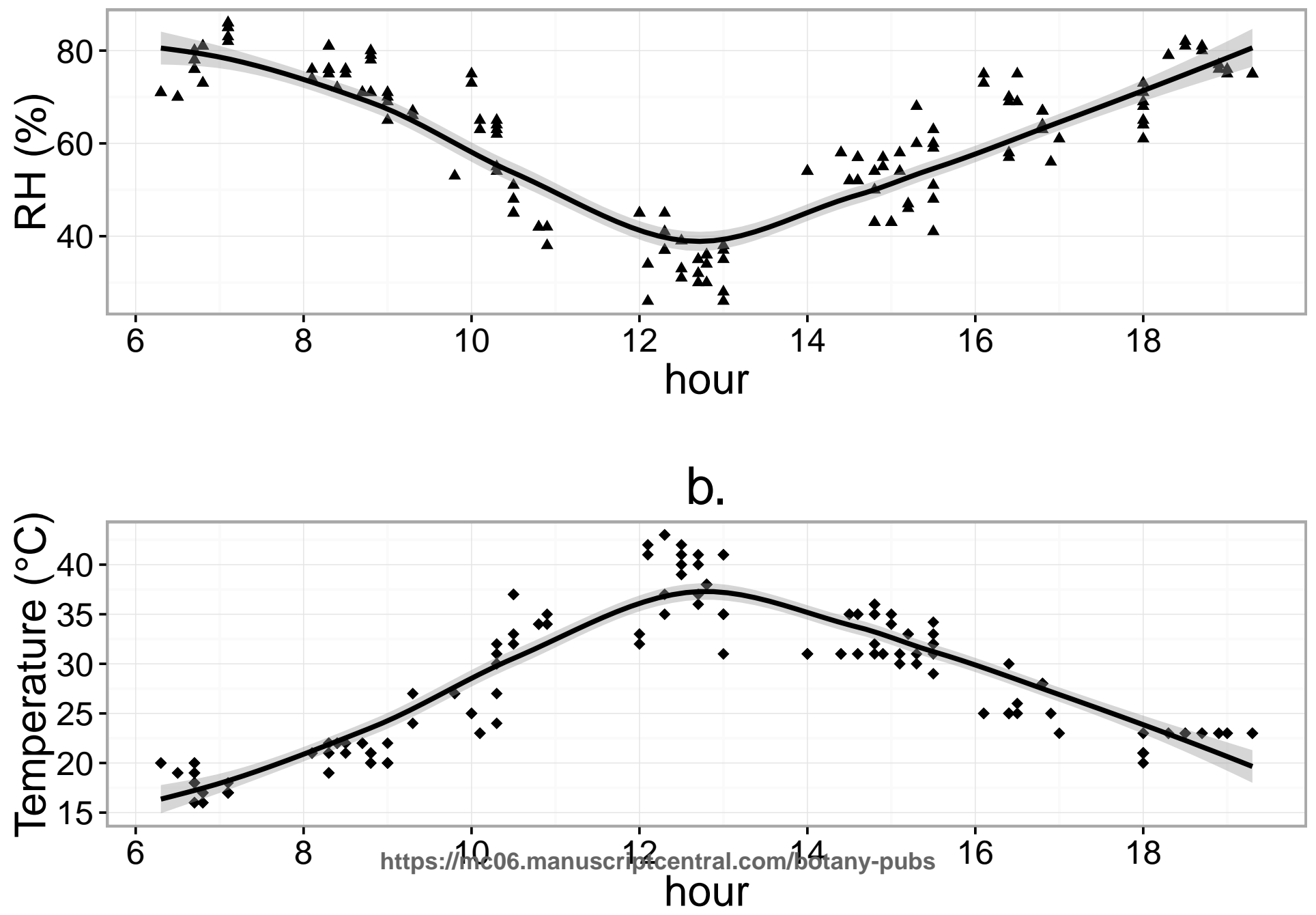

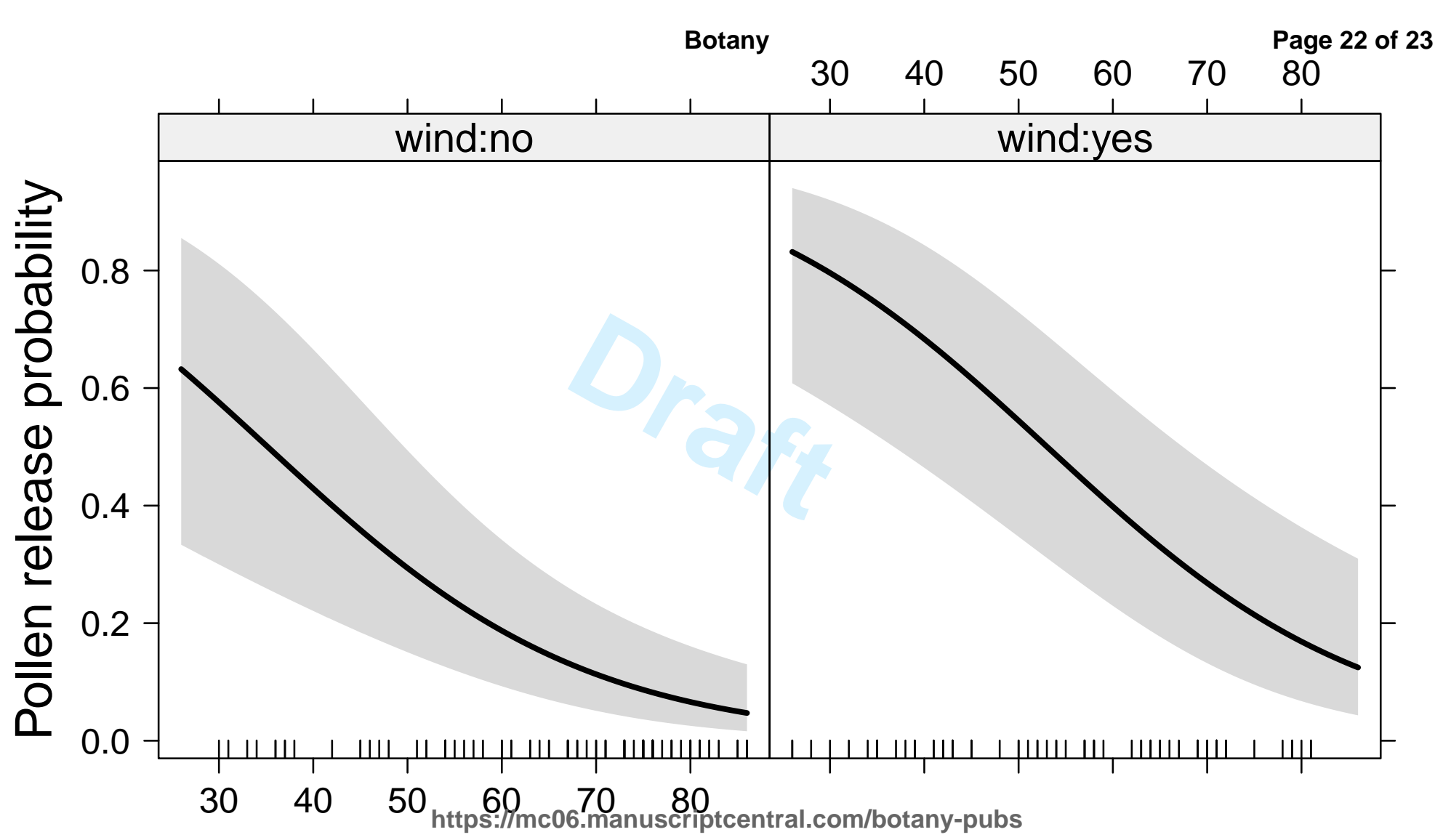

$\mathrm{RH}(\%)$ 


\section{Botany}

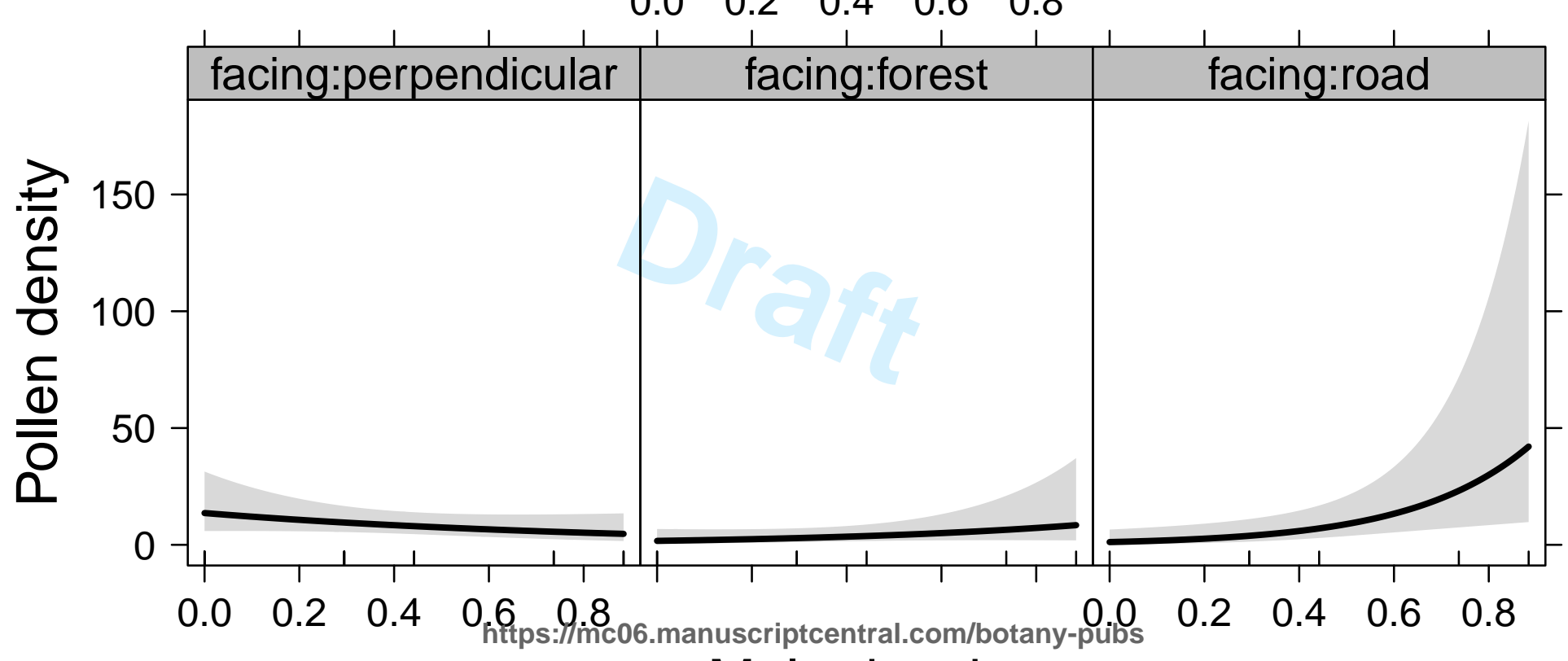

Male density 